\title{
Studi Ekstraksi Bijih Thorit dengan Metode Digesti Asam dan Pemisahan Thorium dari Logam Tanah Jarang dengan Metode Oksidasi-Presipitasi Selektif
}

\author{
Study of Thorite Ore Extraction Using Acid Digestion and Separation of \\ Thorium from Rare Earth Metals Using Selective Oxidation-Presipitation \\ Method
}

\author{
Moch Iqbal Nur Said ${ }^{1 *}$, Mutia Anggraini ${ }^{2}$, Mohammad Zaki Mubarok ${ }^{1}$, Kurnia Setiawan Widana ${ }^{2}$ \\ ${ }^{1}$ Program Studi Teknik Metalurgi, ITB, J1. Ganesha No. 10, Bandung, Indonesia, 40132 \\ ${ }^{2}$ Pusat Teknologi Bahan Galian Nuklir-BATAN, Jl. Lebak Bulus Raya No. 9, Ps. Jumat, Jakarta, Indonesia 12440 \\ *E-mail: iqbalnurs21@yahoo.com
}

Naskah diterima: 5 November 2017, direvisi: 26 November 2017, disetujui: 30 November 2017

DOI: https://doi.org/10.17146/eksplorium.2017.38.2.3930

\begin{abstract}
ABSTRAK
Thorium (Th) merupakan logam radioaktif yang dapat terbentuk bersama uranium dan logam tanah jarang (LTJ). Mineral-mineral yang mengandung unsur radioaktif diantaranya monasit ((Ce,La,Y,U/Th) $\left.\mathrm{PO}_{4}\right)$, thorianit $\left((\mathrm{Th}, \mathrm{U}) \mathrm{O}_{2}\right)$, dan thorit $\left(\mathrm{ThSiO}_{4}\right)$. Daerah Mamuju, Sulawesi Barat diketahui mengandung mineral radioaktif, salah satunya adalah thorit. Untuk memisahkan LTJ dari unsur radioaktif dapat dilakukan dengan cara mengekstraksi thorium dari bijih thorit dengan metode digesti asam menggunakan asam sulfat $\left(\mathrm{H}_{2} \mathrm{SO}_{4}\right)$, kemudian diikuti pelindian dalam air dan rekoveri thorium dalam bentuk thorium hidroksida dengan metode presipitasi kimia menggunakan ammonium hidroksida $\left(\mathrm{NH}_{4} \mathrm{OH}\right)$. Hasil percobaan menunjukkan bahwa kondisi optimum digesti asam yang memberikan persentase ekstraksi paling tinggi didapatkan pada rasio padat/cair 1:2 (g/mL) selama 60 menit dengan persentase ekstraksi Th, besi (Fe), dan LTJ masing-masing sebesar 82,47\%, 80,08\%, dan 83,31\%. Persentase presipitasi Th tertinggi sebesar 95,47\% diperoleh pada $\mathrm{pH} 4,5$ dalam suhu ruangan $\left(26 \pm 1^{\circ} \mathrm{C}\right)$. Pada temperatur yang lebih tinggi, $\left(70^{\circ} \mathrm{C}\right)$, diperoleh persentase presipitasi thorium yang lebih rendah sebesar $83,69 \%$. Pre-oksidasi dengan menggunakan larutan $\mathrm{H}_{2} \mathrm{O}_{2}$ sebanyak dua kali stoikiometri selama 1,5 jam pada suhu kamar meningkatkan persentase presipitasi Fe dari 93,08\% menjadi 99,93\%.
\end{abstract}

Kata kunci: thorium, thorit, digesti asam, ekstraksi, presipitasi

\begin{abstract}
Thorium (Th) is a radioactive metal that can be formed along with uranumand rare earth metals (REM). Minerals contain radioactive elements are monazite ((Ce,La,Y,U/Th)PO $\left.\mathrm{O}_{4}\right)$, thorianite $\left((\mathrm{Th}, \mathrm{U}) \mathrm{O}_{2}\right)$, and thorite $\left(\mathrm{ThSiO}_{4}\right)$. Maтuju Area is containing radioactive minerals, thorite is one of them. To separate REM from radioactive elements can be conducted by exctracting thorium from thorite ore by acid digestion method using sulphuric acid $\left(\mathrm{H}_{2} \mathrm{SO}_{4}\right)$, followed by leaching and thorium recovery in the form of thorium hydroxide by chemical precipitation using ammonium hydroxide $\left(\mathrm{NH}_{4} \mathrm{OH}\right)$. The experimental results showed that the optimum conditions of acid digestion that give the highest Th extraction percentage on solid to liquid ratio are obtained at 1:2 ( $\mathrm{g} / \mathrm{mL})$ in 60 minutes with extraction percentages of $\mathrm{Th}$, iron $(\mathrm{Fe})$ and $\mathrm{REM}$ are $82.47 \%, 80.08 \%$, and $83.31 \%$ respectively. The highest thorium precipitation percentage, as much as $95.47 \%$, was obtained at pH 4.5 on room temperature $\left(26 \pm 1^{\circ} \mathrm{C}\right)$. At higher temperature $\left(70^{\circ} \mathrm{C}\right)$, a lower percentage of thorium precipitation is obtained, as much as $83.69 \%$. Pre-oxidation by using $\mathrm{H}_{2} \mathrm{O}_{2}$ solution with two times stoichiometry for 1.5 hours at room temperature is increasing Fe precipitation percentage from $93.08 \%$ to $99.93 \%$.
\end{abstract}

Keywords: thorium, thorite, acid digestion, extraction, precipitation 


\section{PENDAHULUAN}

Teknologi nuklir merupakan teknologi yang telah banyak dikembangkan dan dimanfaatkan di dunia, khususnya untuk penyediaan energi. Kebutuhan energi di dunia semakin lama semakin meningkat tetapi sumber energi konvensional seperti energi yang bersumber pada bahan bakar fosil semakin berkurang. Pada tahun 2015, kebutuhan energi duniamencapai153.516 TWh dan diprediksi akan terus meningkat sebesar $1,3 \%$ per tahun hingga 20 tahun mendatang [1]. Kebutuhan energi listrik Indonesia pada tahun yang sama mencapai 1.497,9 TWh dan diprediksi menjadi 7.936,3 TWh pada tahun 2050 [2]. Hal ini menjadi tantangan bagi Indonesia dalam menghadapi kebutuhan energi di masa mendatang.

Presiden Republik Indonesia melalui Sidang Paripurna Dewan Energi Nasional (DEN) telah mengesahkan Perpres No. 22 tahun 2017 tentang Rancangan Umum Energi Nasional (RUEN) yang berlandasakan pada PP No. 79 Tahun 2014 tentang Kebijakan Energi Nasional (KEN). Di dalam RUEN, Indonesia ditargetkan memiliki total kapasitas pembangkit listrik sebesar $430 \mathrm{GW}$ (Giga Watt) pada tahun 2050 dimana $31 \%$ dari total kapasitas tersebut harus berasal dari Energi Baru Terbarukan (EBT) dan ditargetkan pada Tahun 2025 sudah tercapai hingga 23\% [3]. Hal ini membuat PLTN berbahan thorium menjadi salah satu opsi yang dipertimbangkan oleh pemerintah untuk memenuhi target tersebut.

Thorium adalah logam radioaktif yang terdapat di alam dan termasuk ke dalam golongan aktinida yang biasanya berikatan dalam suatu mineral bersama dengan uranium dan logam tanah jarang (LTJ). Beberapa mineral thorium yang utama antara lain monasit ((Ce,La,Y,Th) $\left.\mathrm{PO}_{4}\right), \quad$ thorianit
$\left((\mathrm{Th}, \mathrm{U}) \mathrm{O}_{2}\right)$, dan thorit $\left(\mathrm{ThSiO}_{4}\right)$. Isotop thorium paling stabil adalah thorium-232 (Th232) yang merupakan isotop pengemisi alpha dan mempunyai waktu paruh sangat panjang, yaitu sekitar $1,41 \times 10^{10}$ tahun. Dalam reaktor nuklir, Th-232 dapat menyerap neutron menjadi Th-233 yang selanjutnya meluruh dengan sangat cepat (22 menit) menjadi protactinium-233 (Pa-233) dan meluruh lagi menjadi U-233 (27 hari) [4]. Untuk dapat digunakan sebagai bahan bakar reaktor, thorium harus memiliki kemurnian lebih dari $87,42 \%$ [5]. Pemerintah Indonesia melalui PT. Timah (Persero) Tbk. dan BATAN saat ini sedang mengembangkan unit pengolahan konsentrat monasit dari produk samping unit pengolahan bijih timah dan ekstraksi thorium \& Logam Tanah Jarang (LTJ) dari terak peleburan timah [6].

Terdapat berbagai metode untuk mengolah mineral yang mengandung thorium. Salah satu yang paling banyak digunakan dan diaplikasikan dalam penelitian ini adalah dengan metode asam (acid treatment). Mineral thorit direaksikan dengan $\mathrm{H}_{2} \mathrm{SO}_{4}$ pada suhu tinggi sehingga komponenkomponen seperti Th dan LTJ terlarut menjadi senyawa sulfida. Proses ini disebut proses digesti asam. Dalam bentuk senyawa sulfida, Th dan LTJ lebih mudah dipresipitasi menggunakan larutan basa $\mathrm{NH}_{4} \mathrm{OH}$ menjadi senyawa Th dan LTJ hidroksida sehingga komponen tersebut dapat dipisahkan secara selektif. Dalam penelitian ini, besi (Fe) diangggap sebagai komponen pengotor yang secara bersama-sama dengan Th mengendap menjadi senyawa hidroksida. Maka dari itu, penambahan hidrogen peroksida $\left(\mathrm{H}_{2} \mathrm{O}_{2}\right)$ diharapkan dapat mengoksidasi $\mathrm{Fe}$ dan membuat Fe dapat terpisah dengan Th. 


\section{TEORI}

Thorit merupakan salah satu mineral yang mengandung thorium dengan rumus senyawa $\mathrm{ThSiO}_{4}$. Thorit memiliki kandungan thorium sebanyak $7 \%$ sampai $8 \%$ dan silika sekitar 15\%. Terdapat dua metode yang umum digunakan untuk mengekstraksi mineral yang mengandung thorium khususnya monasit, yaitu metode asam (acid treatment) dan metode basa (alkali treatment) [7].

Pada acid treatment, mineral monasit didigesti dengan $\mathrm{H}_{2} \mathrm{SO}_{4} 98 \%$ pada suhu $200^{\circ} \mathrm{C}-220^{\circ} \mathrm{C}$ dengan perbandingan padat/cair tertentu hingga membentuk slury berwarna abu-abu atau disebut gray mud.Gray mud kemudian dilakukan pelindian dalam air agar dapat dilakukan pemisahan padat-cair. Selanjutnya dilakukan pengendapan secara parsial untuk memisahkan masing-masing komponen Th, U, dan LTJ yang terkandung dalam larutan menggunakan $\mathrm{NH}_{4} \mathrm{OH}$ hingga $\mathrm{pH}$ tertentu. Pada alkali treatment, monasit dilakukan proses alkali fusi menggunakan $\mathrm{NaOH} 65 \%$ pada suhu $140^{\circ} \mathrm{C}$ untuk mendekomposisi komponennya menjadi padatan hidroksida. Pemisahan parsial antar komponennya dilakukan dengan pelarutan menggunakan asam pada $\mathrm{pH}$ tertentu.

Percobaan digesti asam monasit yang mengandung thoritdiinterpretasikan terjadi reaksi dengan persamaan reaksi [8]:

$$
\begin{aligned}
& 2(\mathrm{LTJ})\left(\mathrm{PO}_{4}\right)+3 \mathrm{H}_{2} \mathrm{SO}_{4} \rightarrow(\mathrm{LTJ})_{2}\left(\mathrm{SO}_{4}\right)_{4}+2 \mathrm{H}_{3} \mathrm{PO}_{4} \\
& \mathrm{ThSiO}_{4}+2 \mathrm{H}_{2} \mathrm{SO}_{4} \rightarrow \mathrm{Th}\left(\mathrm{SO}_{4}\right)_{2}+\mathrm{SiO}_{2}+\mathrm{H}_{2} \mathrm{O} \\
& 2 \mathrm{ThPO}_{4}+3 \mathrm{H}_{2} \mathrm{SO}_{4} \rightarrow \mathrm{Th}_{2}\left(\mathrm{SO}_{4}\right)_{3}+2 \mathrm{H}_{3} \mathrm{PO}_{4} \\
& \mathrm{Fe}_{2} \mathrm{O}_{3}+3 \mathrm{H}_{2} \mathrm{SO}_{4} \rightarrow \mathrm{Fe}_{2}\left(\mathrm{SO}_{4}\right)_{3}+3 \mathrm{H}_{2} \mathrm{O} \\
& \mathrm{SiO}_{2} \cdot \mathrm{xH}_{2} \mathrm{O}+\mathrm{H}_{2} \mathrm{SO}_{4} \rightarrow \mathrm{SiO}_{2}+\mathrm{H}_{2} \mathrm{SO}_{4} \cdot \mathrm{xH}_{2} \mathrm{O}
\end{aligned}
$$

Larutan kaya thorium kemudian ditambahkan $\mathrm{NH}_{4} \mathrm{OH}$ agar terjadi presipitasi seperti pada reaksi:

$\mathrm{Th}\left(\mathrm{SO}_{4}\right)_{2}+4 \mathrm{NH}_{4} \mathrm{OH} \rightarrow \mathrm{Th}(\mathrm{OH})_{4}+2\left(\mathrm{NH}_{4}\right)_{2} \mathrm{SO}_{4}$

Persentase ekstraksi dan persentase presipitasi masing-masing dihitung menggunakan persamaan:

$$
\begin{gathered}
\% \text { Ekstraksi }=\frac{w_{\text {Larut }}}{w_{\text {Biji }}} \times 100 \% \\
\% \text { Presipitasi }=\frac{w_{\text {Awal }}-w_{\text {Akhir }}}{w_{\text {Awal }}} \times 100 \%
\end{gathered}
$$

Keterangan:

$w_{\text {Larut }}=$ Berat logam terlarut

$w_{B i j i}=$ Berat logam di bijih

$w_{\text {Awal }}=$ Berat logam terlarut awal

$w_{\text {Akhir }}=$ Berat logam terlarut akhir

\section{METODOLOGI}

\section{Bahan Baku}

Sampel bijih yang digunakan dalam penelitian ini adalah bijih thorit yang berasal dari Kabupaten Mamuju, Provinsi Sulawesi Barat. Komposisi kimia bijih thorit hasil pengujian XRF dan hasil analisis komposisi mineral yang dominan dalam bijih dengan menggunakan XRD ditunjukkan masingmasing pada Tabel 1 dan Gambar 1.

Hasil pengujian XRF menunjukkan bahwa unsur yang paling dominan dalam bijih thorit adalah $\mathrm{Si}$, Th, Fe dan dari unsur LTJ berupa Ce dan Nd. Hasil pengujian XRD menunjukkan bahwa mineral dominan dalam sampel adalah kuarsa $\left(\mathrm{SiO}_{2}\right)$, thorit $\left(\mathrm{ThSiO}_{4}\right)$, dan kolumbit $\left(\mathrm{FeNb}_{2} \mathrm{O}_{6}\right)$. 
Tabel 1.Komposisi kimia bijih thorit hasil pengujian XRF.

\begin{tabular}{cccc}
\hline Senyawa & \% & Unsur & $\%$ \\
\hline $\mathrm{Al}_{2} \mathrm{O}_{3}$ & 13,60 & $\mathrm{Al}$ & 3,60 \\
$\mathrm{SiO}_{2}$ & 32,47 & $\mathrm{Si}$ & 15,15 \\
$\mathrm{P}_{2} \mathrm{O}_{5}$ & 3,66 & $\mathrm{P}$ & 0,80 \\
$\mathrm{~K}_{2} \mathrm{O}$ & 6,74 & $\mathrm{~K}$ & 2,80 \\
$\mathrm{CaO}$ & 0,50 & $\mathrm{Ca}$ & 0,03 \\
$\mathrm{TiO} \mathrm{O}_{2}$ & 1,66 & $\mathrm{Ti}$ & 0,99 \\
$\mathrm{MnO}$ & 0,10 & $\mathrm{Mn}$ & 0,07 \\
$\mathrm{Fe}_{2} \mathrm{O}_{3}$ & 24,67 & $\mathrm{Fe}$ & 8,63 \\
$\mathrm{CoO}$ & 0,02 & $\mathrm{Co}$ & 0,02 \\
$\mathrm{CuO}$ & 0,02 & $\mathrm{Cu}$ & 0,01 \\
$\mathrm{ZnO}$ & 0,01 & $\mathrm{Zn}$ & 0,01 \\
$\mathrm{ZrO}_{2}$ & 0,27 & $\mathrm{Zr}$ & 0,20 \\
$\mathrm{La}_{2} \mathrm{O}_{3}$ & 0,68 & $\mathrm{La}$ & 0,29 \\
$\mathrm{Ce}_{2} \mathrm{O}_{3}$ & 1,75 & $\mathrm{Ce}$ & 0,75 \\
- & - & $\mathrm{Nd}$ & 0,45 \\
- & - & $\mathrm{Er}$ & 0,01 \\
- & - & $\mathrm{Yb}$ & 0,00 \\
- & - & $\mathrm{Th}$ & 7,16 \\
- & - & $\mathrm{U}$ & 0,28 \\
- & - & $\mathrm{Y}$ & 0,18 \\
\hline
\end{tabular}

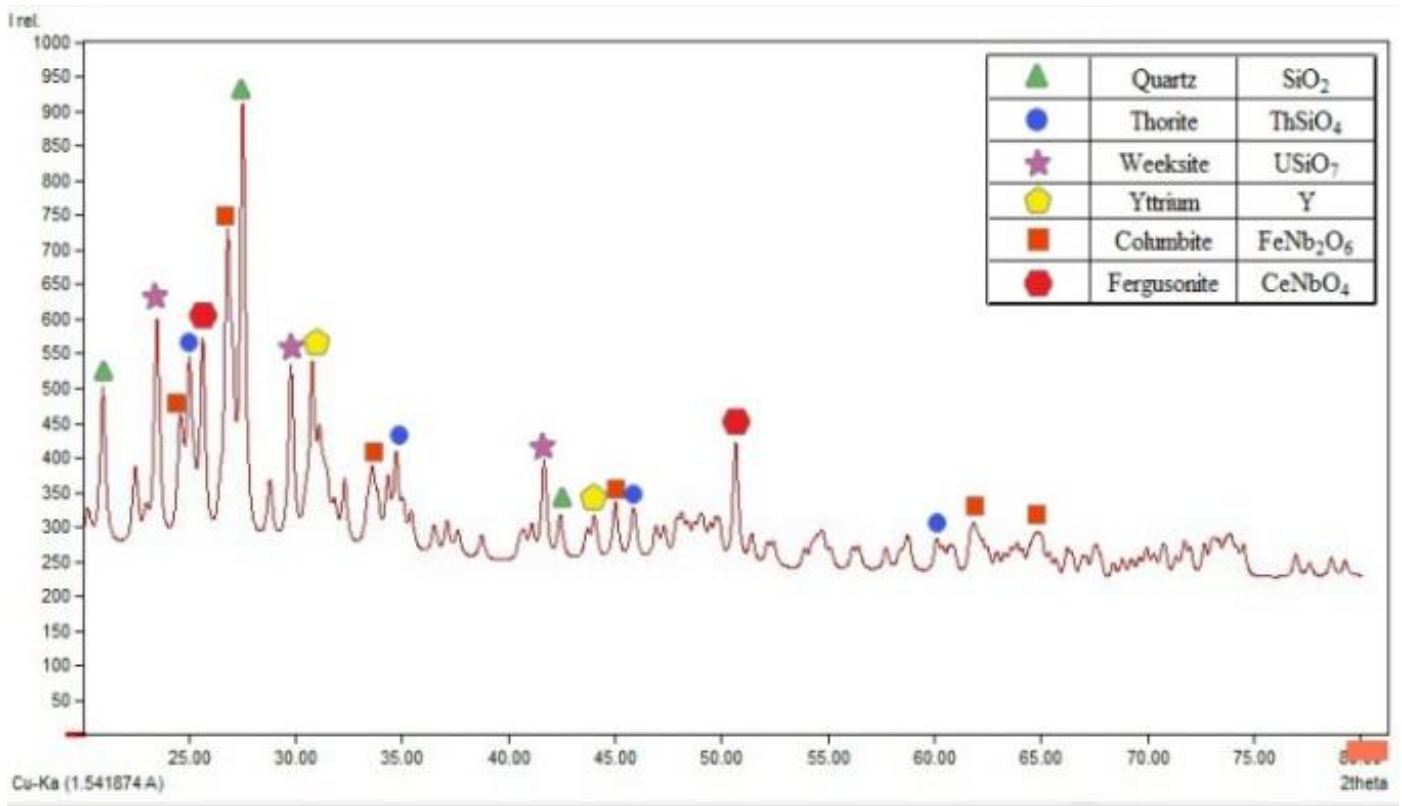

Gambar 1. Hasil analisis komposisi mineral yang dominan dengan menggunakan XRD.

\section{Prosedur Percobaan}

Sampel bijih dilakukan kominusi terlebih dahulu kemudian dilakukan digesti asam, pelindian dalam air, dan diikuti oleh presipitasi. Secara umum diagram alir percobaan dapat dilihat dalam diagram alir pada Gambar 2. 


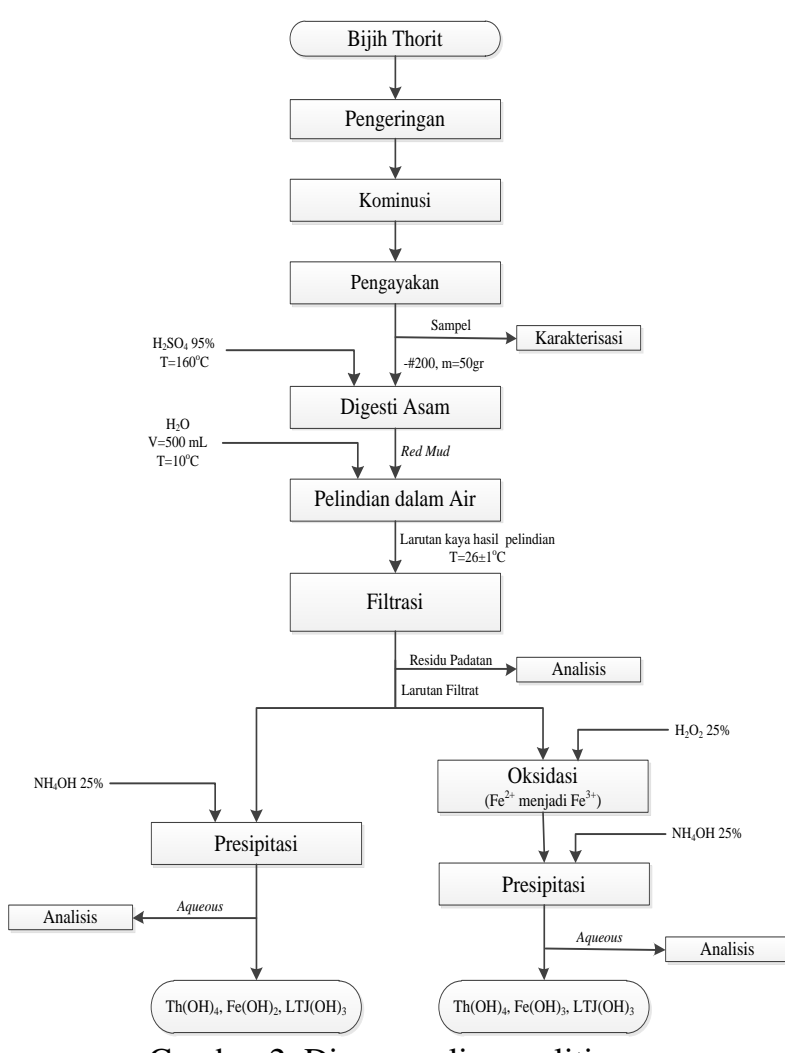

Gambar 2. Diagram alir penelitian.

\section{Reduksi Ukuran Bijih dan Klasifikasi Ukuran}

Kominusi terdiri dari peremukan menggunakan jaw crusher dan penggerusan menggunakan rod mill selama 1 jamdengan perbandingan berat bijih:rod adalah 1:4. Kemudian bijih dikeringkan dalam sebuah oven dengan suhu $105^{\circ} \mathrm{C}$ selama 8 jam. Bijih yang telah kering kemudian dilakukan klasifikasi ukuran dengan vibrating screen sehingga didapatkan ukuran butiran -200\# atau setara dengan $74 \mu \mathrm{m}$.

\section{Percobaan Digesti Asam}

Percobaan ini dilakukan dalam gelas beker $300 \mathrm{~mL}$ yang terintegrasi dengan hot plate dan pengaduk mekanik yang menggunakan pengaduk jenis impeller 4-blade radial turbine yang terbuat dari PTFE/teflon. Sebanyak 50gram sampel bijih dimasukkan ke dalam gelas beker yang sudah ditambahkan larutan $\mathrm{H}_{2} \mathrm{SO}_{4} 98 \%$ dengan volume tertentu pada suhu $160^{\circ} \mathrm{C}$.
Pengadukan dilakukan selama waktu yang ditentukan dengan kecepatan $175 \mathrm{rpm}$. Setelah pengadukan selesai, terbentuk grey mud yang kemudian dilakukan pelindian di dalam air dengan tujuan melarutkan Th dan memisahkannya dari unsur-unsur pengotor yang tidak membentuk senyawa sulfat, khususnya Si dan Al. Selanjutnya dilakukan pemisahan antara larutan kaya Th dengan residu yang tidak larut menggunakan rangkaian vacuum filter.

Percobaan digesti asam ini dilakukan dengan variasi waktu digesti $30 ; 40 ; 60 ; 120$; 180; dan 240 menit dengan perbandingan padat:cair 1:2 (g/mL). Digesti asam juga dilakukan dalam variasi perbandingan padat:cair yaitu pada perbandingan $1: 1 ; 1: 1,5$; $1: 2 ; 1: 2,5 ;$ dan $1: 3(\mathrm{~g} / \mathrm{mL})$.

\section{Percobaan Presipitasi Thorium}

Larutan kaya hasil pelindian kemudian dilakukan netralisasi dengan penambahan larutan $\mathrm{NH}_{4} \mathrm{OH}$ untuk mengendapkan thorium terlarut. Presipitasi dilakukan di dalam gelas beker yang terintegrasi dengan $\mathrm{E}_{\mathrm{h}}-\mathrm{pH}$ meter, magnetic stirrer, dan hot plate. Presipitasi di lakukan dalam tekanan atmosfer, kecepatan putaran $300 \mathrm{rpm}$, dan temperatur yang telah ditentukan. Percobaan presipitasi ini dilakukan dengan variasinilai $\mathrm{pH} 1$ hingga 4,5 dengan kenaikan $\mathrm{pH}$ setiap 0,5 serta variasi temperatur presipitasi pada $\mathrm{pH}$ 3,5 dengan suhu 40, 50, 60, dan $80^{\circ} \mathrm{C}$. Presipitat kemudian dipisahkan antara fase padatan dan cairan menggunakan centrifuge.

\section{Oksidasi Besi}

Dalam penelitian ini, unsur besi dianggap sebagai pengotor. Fe kemudian ikut larut pada tahap pelindian dalam air menjadi senyawa besi sulfat dan terpresipitasi bersamaan dengan Th membentuk senyawa 
besi hidroksida. Pre-oksidasi besi dengan menggunakan $\mathrm{H}_{2} \mathrm{O}_{2}$ bertujuan untuk mengoksidasi $\mathrm{Fe}^{2+}$ menjadi $\mathrm{Fe}^{3+}$ yang selanjutnya dapat dipresipitasi pada $\mathrm{pH}$ larutan yang lebih rendah. Penambahan $\mathrm{H}_{2} \mathrm{O}_{2}$ sebanyak dua kali stoikiometri dari besi dalam larutan dilakukan sebelum proses netralisasi menggunakan $\mathrm{NH}_{4} \mathrm{OH}$.

\section{Analisis}

Pada penelitian ini, analisis kandungan unsur dan senyawa dalam padatan dilakukan masing-masing dengan menggunakan $X$-Ray Flourosence (XRF) dan X-Ray Diffraction (XRD). Sementara itu, analisis kandungan unsur LTJ, Fe, dan Th terlarut dilakukan masing-masing dengan menggunakan Inductively Coupled Plasma Optical Emission Spectrometer (ICP-OES), Atomic Absorption Spectrophotometer (AAS), dan UltravioletVisible Spectrophotometry (UV-VIS).

\section{HASIL DAN PEMBAHASAN}

\section{Pengaruh Waktu Digesti Asam Terhadap Persentase Ekstraksi Th, Fe, dan LTJ}

Persentase ekstraksi Th, Fe, dan LTJ dari percobaan digesti asam dan pelindian dalam air dengan berbagai waktu pengadukan disajikan pada Gambar 3. Dapat dilihat bahwa secara umum semakin lama waktu digesti, semakin tinggi persentase ekstraksi Th, Fe, dan LTJ. Digesti asam selama 60 menit dianggap sebagai waktu proses terbaik karena menghasilkan perolehan Th sebesar $82,47 \%$, dengan Fe dan LTJ terlarut masingmasing sebesar $80,08 \%$ dan $83,31 \%$. Peningkatan waktu pengadukan lebih dari 60 menit menyebabkan peningkatan besi yang ikut terlarut sekitar 18\% menjadi 98\% (pada waktu pelindian selama 120 menit) sedangkan persentase perolehan Th stabil di sekitar $82 \%$. Persentase perolehan Th dari bijih monasit melalui digesti asam dan pelarutan dalam air disebabkan karena pasir monasit belum terdekomposisi secara sempurna pada suhu digesti dibawah $180^{\circ} \mathrm{C}$ [9] seperti yang ditunjukan oleh profil persentase monasit terdekomposisi sebagai fungsi suhu pada Gambar 4. Hal yang sama mengindikasikan bahwa untuk mineral thorit pada percobaan ini juga belum terdekomposisi sempurna karena suhu percobaan maksimum yang dilakukan yaitu $160^{\circ} \mathrm{C}$ sehingga menyebabkan mineral thorium tidak seluruhnya membentuk senyawa sulfat. Akibatnya hanya $82,5 \%$ unsur Th yang terlarut pada tahap pelindian dengan air. Di sisi lain, bila temperatur proses dinaikkan hingga $230^{\circ} \mathrm{C}$ maka dapat terbentuk senyawa thorium pyrophosphate $\left(\mathrm{ThP}_{2} \mathrm{O}_{7}\right)$ yang tidak larut dan terbawa ke dalam residu.

\section{Pengaruh Perbandingan Padat/Cair Terhadap Persentase Ekstraksi Th, Fe, dan LTJ}

Grafik hubungan persentase Th, Fe, dan LTJ terhadap perbandingan padat/cair $(\mathrm{g} / \mathrm{mL})$ antara bijih dan $\mathrm{H}_{2} \mathrm{SO}_{4}$ pada proses digesti asam yang dilakukan selama 60 menit pengadukan pada berbagai rasio padat/cair tersaji dalam Gambar 5. Dapat dilihat bahwa persentase ekstraksi Th dan LTJ mencapai nilai maksimum pada perbandingan padat/cair $1: 2$, yaitu masing-masing sebesar $82,47 \%$ dan $83,31 \%$. 


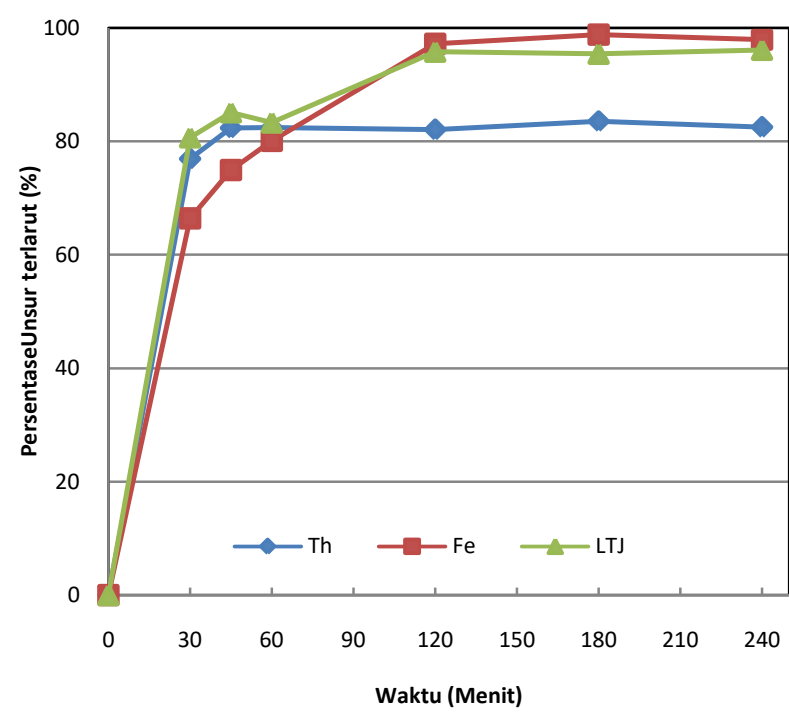

Gambar 3. Grafik hubungan persentase Th, Fe, dan LTJ tarlarut terhadap waktu pada proses digesti asam (suhu $160^{\circ} \mathrm{C}$, rasio padat/cair $1: 2 \mathrm{~g} / \mathrm{mL}$ ).

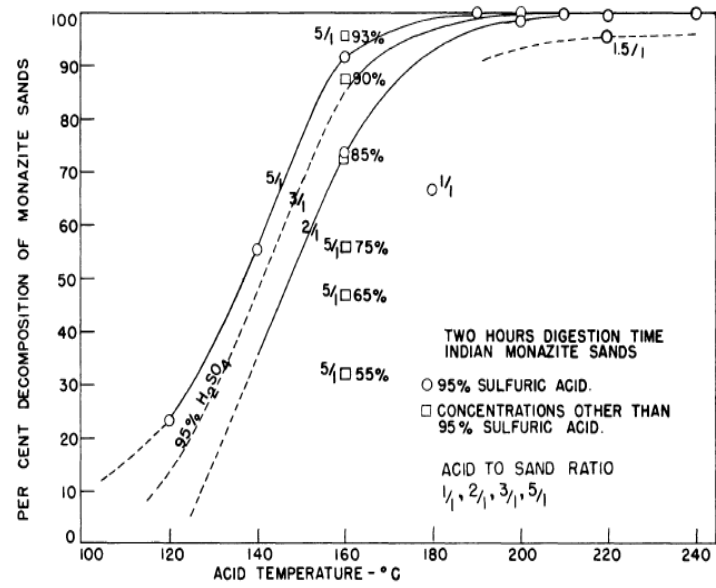

Gambar 4. Grafik persentase dekomposisi monasit sebagai fungsi temperatur pada berbagai perbandingan padat/cair dan konsentrasi $\mathrm{H}_{2} \mathrm{SO}_{4}$ pada proses digesti asam[8].

Sementara itu, Fe paling banyak terekstraksi pada perbandingan padar/cair 1:3 (g/mL), yaitu sebesar 97,74\%. Terlihat bahwa semakin besar perbandingan padat/cair, Th dan LTJ yang terlarut cenderung semakin menurun sementara Fe semakin naik.

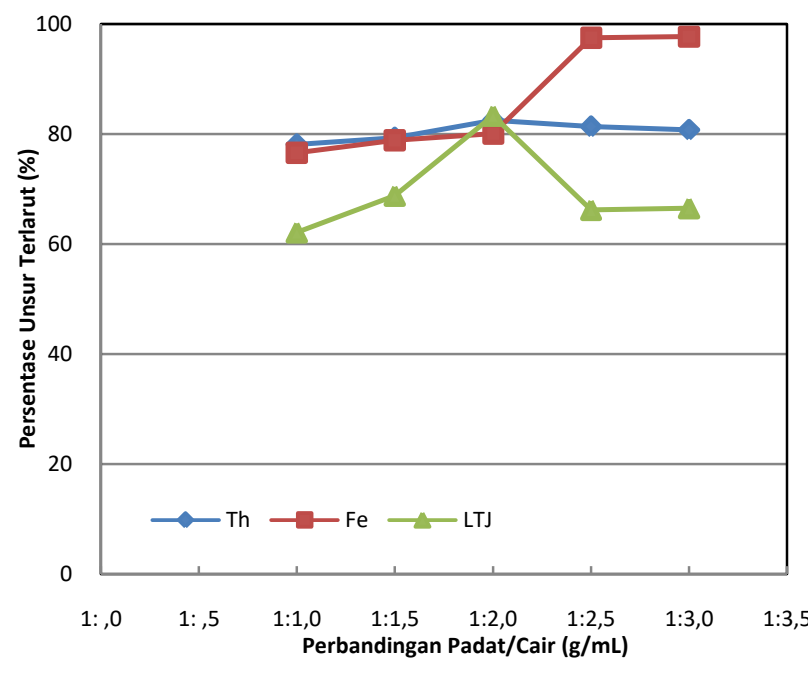

Gambar 1. Grafik hubungan persentase Th, Fe, dan LTJ terlarut terhadap perbandingan padat/cair $(\mathrm{g} / \mathrm{mL})$ antara bijih dan $\mathrm{H}_{2} \mathrm{SO}_{4}$ pada proses digesti asam selama $1 \mathrm{jam}$.

\section{Pengaruh Nilai pH Terhadap Persentase Presipitasi Th, Fe, dan LTJ}

Grafik hubungan antara persentase presipitasi Th, Fe, dan LTJ akibat kenaikan $\mathrm{pH}$ pada proses presipitasi dengan penambahan $\mathrm{NH}_{4} \mathrm{OH}$ pada suhu ruangan $\left(26 \pm 1^{\circ} \mathrm{C}\right)$ dapat dilihat pada Gambar 6. Secara umum, semakin tinggi $\mathrm{pH}$ larutan maka persentase presipitasi Th, Fe, dan LTJ juga semakin meningkat. Persentase presipitasi dari Th, Fe, LTJ paling tinggi diperoleh pada pH 4,5; yaitu masing-masing sebesar 95,47\%, 93,08\%, dan 27,99\%. Persentase presipitasi LTJ signifikan lebih rendah daripada Th dan Fe.Hal ini sesuai dengan hasil percobaan dimana LTJ terpresipitasi sempurna padapH di atas 5,8 menjadi senyawa $\operatorname{LTJ}(\mathrm{OH})_{3}[10]$. LTJ dalam filtrat dapat dimurnikan lebih lanjut dengan metode-metode pemurnian seperti ekstraksi pelarut dan adsorbsi selektif menggunakan resin penukar ion. 


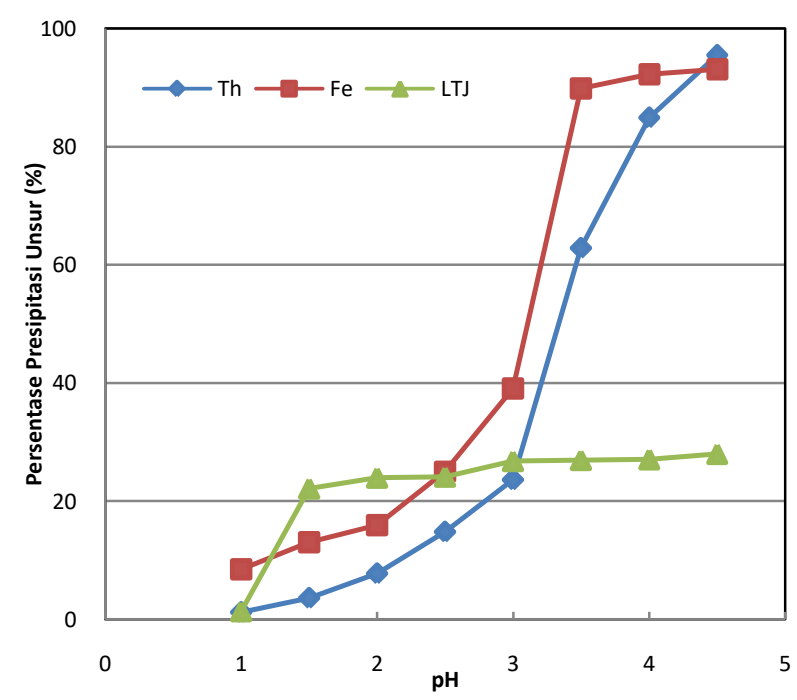

Gambar 6. Grafik hubungan persentase presipitasi Th, Fe, dan LTJ terhadap kenaikan $\mathrm{pH}$ pada proses presipitasi dengan penambahan $\mathrm{NH}_{4} \mathrm{OH}$.

\section{Pengaruh Temperatur Pada Persentase Presipitasi Th, Fe, dan LTJ}

Grafik hubungan antara persentase presipitasi Th, Fe, dan LTJ dengan kenaikan temperatur pada proses presipitasi oleh penambahan $\mathrm{NH}_{4} \mathrm{OH}$ disajikan pada Gambar 7, dapat dilihat bahwa pada profil persentase presipitasi Th, jika ditarik garis regresi cenderung mempunyai pola menurun seiring dengan naiknya temperatur larutan, semakin tinggi temperatur, maka thorium yang terpresipitasi menjadi senyawa hidroksida cenderung semakin menurun [11]. Kenaikan temperatur pada larutan, meningkatkan jumlah ion hidroksil $\left(\mathrm{OH}^{-}\right)$bebas dalam larutan [12]. Akibatnya, Th semakin sulit untuk membentuk senyawa thorium hidroksida $\left(\mathrm{Th}(\mathrm{OH})_{4}\right)$.

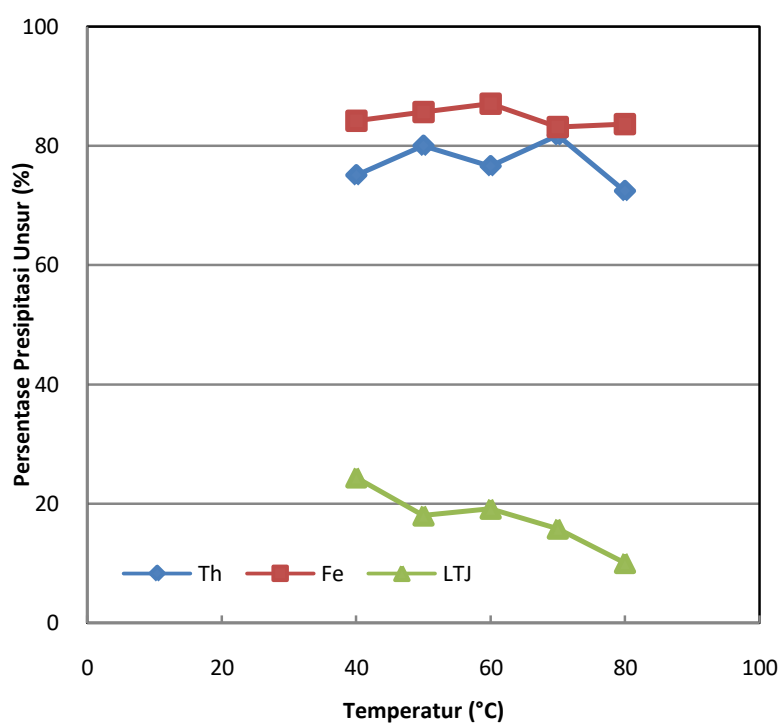

Gambar 8. Grafik hubungan persentase presipitasi Th, Fe, dan LTJ terhadap temperatur presipitasi di $\mathrm{pH}$ 3,5 pada proses presipitasi dengan penambahan $\mathrm{NH}_{4} \mathrm{OH}$.

\section{Pengaruh Pre-oksidasi dengan $\mathrm{H}_{2} \mathrm{O}_{2}$ Pada Presipitasi Hidroksida}

Profil persentase presipitasi $\mathrm{Th}, \mathrm{Fe}$, dan LTJ sebagai fungsi $\mathrm{pH}$ pada suhu ruangan $\left(26 \pm 1^{\circ} \mathrm{C}\right)$ dan persentase presipitasi pada variasi temperatur di $\mathrm{pH}$ 3,5 dari larutan yang telah dilakukan pre-oksidasi menggunakan $\mathrm{H}_{2} \mathrm{O}_{2}$ dengan dosis dua kali stoikiometri $\mathrm{Fe}$ disajikan masing-masing pada Gambar 8 dan Gambar 9. Pada Gambar 8 dapat dilihat bahwa persentase presipitasi Th, Fe, dan LTJ semakin meningkat seiring dengan nilai $\mathrm{pH}$ larutan yang terus bertambah. Persentase presipitasi $\mathrm{Th}, \mathrm{Fe}$, dan LTJ paling tinggi diperoleh pada $\mathrm{pH} 4,5$ yang secara berurutan memiliki nilai 98,90\%; 99,93\%; dan 25,30\%. Jika dibandingkan dengan presipitasi tanpa pre-oksidasi (Gambar 6), persentase presipitasi Th dan Fe pada percobaan oksidasi-presipitasi memiliki nilai yang lebih tinggi, sementara LTJ memiliki nilai yang lebih rendah. Pada $\mathrm{pH} 3$, persentase presipitasi $\mathrm{Fe}$ yang dihasilkan dari proses oksidasi-presipitasi memiliki nilai 29\% lebih besar daripada presipitasi tanpa pre-oksidasi. Sementara itu, persentase presipitasi Th 
relatif sama. Hal ini menunjukkan bahwa dengan penambahan $\mathrm{H}_{2} \mathrm{O}_{2} 25 \%$ sebanyak dua kali stoikiometri terhadap Fe terlarut dapat mengendapkan besi lebih banyak pada $\mathrm{pH}$ yang lebih rendah.

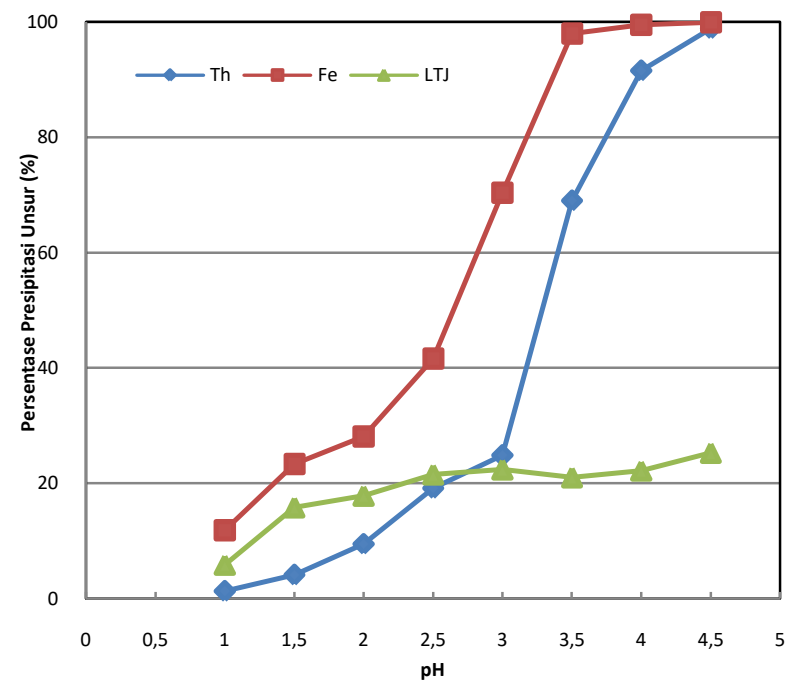

Gambar 8. Grafik hubungan persentase presipitasi Th, Fe, dan LTJ terhadap kenaikan nilai $\mathrm{pH}$ pada proses oksidasipresipitasi hidroksida.

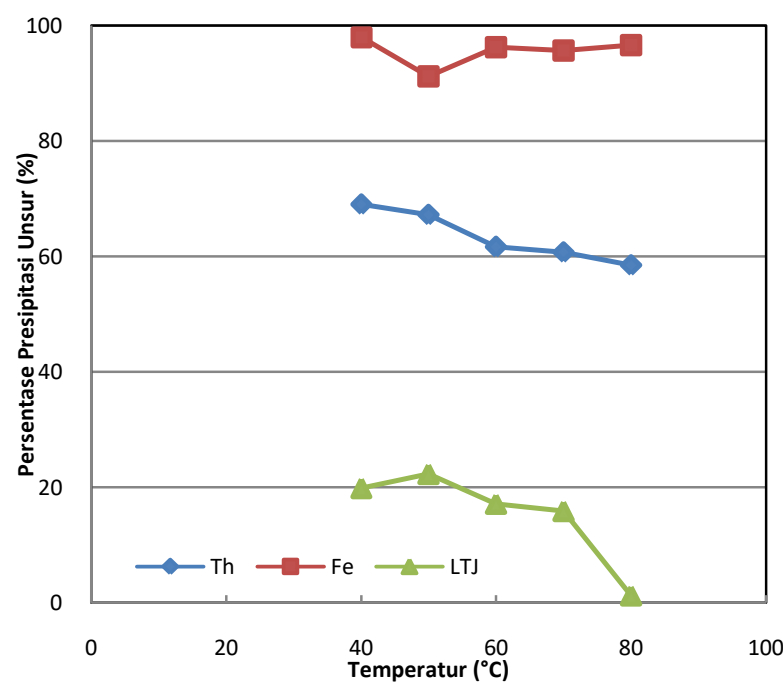

Gambar 9. Grafik hubungan persentase presipitasi Th, Fe, dan LTJ terhadap temperatur presipitasi di $\mathrm{pH} 3,5$ pada proses oksidasi-presipitasi hidroksida.

Berdasarkan persamaan Arrhenius, secara umum semakin tinggi suhu, laju reaksi kimia semakin meningkat. Dari grafik persentase presipitasi pada Gambar 9, dapat dilihat bahwa secara umum persentase presipitasi Fe cenderung stabil di 95\% sampai
96\%, namun persentase presipitasi Th dan LTJ cenderung menurun seiring naiknya temperatur. Persentase presipitasi Th dan LTJ yang terendah diperoleh pada suhu $80^{\circ} \mathrm{C}$, yaitu masing-masing sebesar 58,50\% dan $1,25 \%$. Kelarutan oksigen yang dihasilkan dari dekomposisi $\mathrm{H}_{2} \mathrm{O}_{2}$ cenderung semakin menurun dengan naiknya temperatur sehingga menyebabkan keefektifan proses oksidasi yang diharapkan juga mengalami penurunan $[13,14]$. Oksigen terlarut terbentuk melalui reaksi dekomposisi hidrogen peroksida menjadi oksigen dan air seperti persamaan berikut:

$2 \mathrm{H}_{2} \mathrm{O}_{2} \rightarrow \mathrm{O}_{2}+2 \mathrm{H}_{2} \mathrm{O}$

Oksigen hasil dari dekomposisi hidrogen peroksida memiliki kelarutan tertentu. Semakin tinggi temperatur proses maka semakin banyak oksigen yang terdekomposisi namun semakin sedikit jumlah oksigen yang dapat larut. Pengamatan secara visual menunjukkan bahwa semakin tinggi temperatur proses, semakin banyak gas (diperkirakan sebagai oksigen) yang terbentuk dari dalam larutan sulfat dan keluar dari dalam reaktor setelah ditambahkan dengan $\mathrm{H}_{2} \mathrm{O}_{2}$. Kadar oksigen terlarut mengalami penurunan yang cukup signifikan dalam larutan asam kaya Th di berbagai temperatur percobaan setelah ditambahkan dengan $\mathrm{H}_{2} \mathrm{O}_{2}$ [15]. Penurunan kadar oksigen terlarut di dalam larutan menyebabkan nilai potensial $\left(\mathrm{E}_{\mathrm{h}}\right)$ larutan juga ikut menurun. Seperti hasil-hasil penelitian sebelumnya, hasil pengukuran $E_{h}$ pada penelitian ini menunjukkan bahwa dengan semakin naiknya temperatur, potensial yang terukur semakin rendah.Nilai $E_{h}$ pada variasi temperatur percobaan oksidasi-presipitasi di $\mathrm{pH}$ 3,5 dapat dilihat pada Tabel 2. 
Tabel 2. Nilai $\mathrm{E}_{\mathrm{h}}$ pada variasi $\mathrm{pH}$ dan variasi temperatur percobaan oksidasi-presipitasi di pH 3,5.

\begin{tabular}{cc}
\hline Temperatur $\left({ }^{\circ} \mathbf{C}\right)$ & $\mathbf{E}_{\mathbf{h}}(\mathbf{m V})$ \\
\hline 40 & 588 \\
50 & 560 \\
60 & 550 \\
70 & 528 \\
80 & 515 \\
\hline
\end{tabular}

Pada Tabel 2, ditunjukkan bahwa semakin tinggi temperatur proses presipitasi, nilai $E_{h}$ semakin menurun. Nilai $E_{h}$ pada $p H$ tertentu mempengaruhi reaksi reduksioksidasi (redoks) logam, ion, dan senyawa yang dapat diperkirakan menggunakan diagram $\mathrm{E}_{\mathrm{h}}-\mathrm{pH}$ (Diagram Pourbaix). Ketika $\mathrm{NH}_{4} \mathrm{OH}$ ditambahkan ke dalam larutan asam sulfat kayaTh yang sebelumnya telah dicampur dengan $\mathrm{H}_{2} \mathrm{O}_{2}$ terbentuk senyawa thorium peroksida yang disebut sebagai thorium superoxide $\left(\mathrm{Th}_{2} \mathrm{O}_{7}\right)$ [16] sesuai dengan Persamaan (8) seperti di bawah ini:

$4 \mathrm{Th}^{4+}+3 \mathrm{H}_{2} \mathrm{O}_{2}+\mathrm{H}_{2} \mathrm{O} \rightarrow \mathrm{Th}_{2} \mathrm{O}_{7}+8 \mathrm{H}^{+}$

Dari Persamaan (8) dapat dilihat bahwa pembentukan $\mathrm{Th}_{2} \mathrm{O}_{7}$ memerlukan jumlah mol oksigen yang cukup banyak ( 7 mol oksigen per 2 mol Th). Dengan semakin berkurangnya jumlah oksigen terlarut dan ketidakstabilan ion hidoksil karena kenaikan temperatur proses mengakibatkan penurunan persentase presipitasi Th karena cenderung sulit untuk membentuk senyawa thorium hidroksida.

Pada komponen LTJ, penurunan persentase presipitasi dapat disebabkan oleh reaksi redoks yang menyebabkan perubahan valensi dari ion LTJ. Dalam penelitian ini, komponen LTJ yang memiliki kandungan tertinggi dalam sampel adalah serium (Ce). Ion serium trivalen $\left(\mathrm{Ce}^{3+}\right)$ hasil dekomposisi senyawa $\mathrm{Ce}(\mathrm{PO})_{4}$ dari monasit dapat teroksidasi menjadi ion serium tetravalen
$\left(\mathrm{Ce}^{4+}\right)$ di dalam asam kuat atau karena adanya kandungan oksigen terlarutpada proses presipitasi [17]. Penambahan $\mathrm{H}_{2} \mathrm{O}_{2}$ ke dalam larutan kaya $\mathrm{Ce}$ dapat menghasilkan reaksi yang berbeda tergantung pada nilai $\mathrm{pH}$ [18]. Penambahan $\mathrm{H}_{2} \mathrm{O}_{2}$ dapat berfungsi sebagai reduktor bagi ion $\mathrm{Ce}^{4+}$ dengan membentuk hidrogen radikal $\left(\mathrm{OH}^{\circ}\right)$ pada $\mathrm{pH}<4$, sementarapada $\mathrm{pH}>4 \quad \mathrm{H}_{2} \mathrm{O}_{2}$ berfungsi sebagai oksidator bagi ion $\mathrm{Ce}^{3+}$. Jika dilihat dari diagram Pourbaix sistem $\mathrm{Ce}-\mathrm{H}_{2} \mathrm{O}$ pada Gambar 11, ion $\mathrm{Ce}^{4+}$ lebih mudah untuk dilakukan presipitasi pada $\mathrm{pH}$ rendah menjadi senyawa serium (IV) hidroksida $\left(\mathrm{Ce}(\mathrm{OH})_{4}\right)$ daripada ion $\mathrm{Ce}^{3+}$. Dengan adanya reduksi ion $\mathrm{Ce}^{4+}$ akibat penambahan $\mathrm{H}_{2} \mathrm{O}_{2}$, dan berkurangnya kandungan oksigen terlarut karena kelarutan yang semakin turun dengan naiknya temperatur menyebabkan komponen LTJ telah terpresipitasi sebagian pada $\mathrm{pH}$ rendah dan persentase presipitasinya semakin menurun pada temperatur proses yang lebih tinggi. Karena karakteristik sifat fisik dan kimia yang hampir sama dengan $\mathrm{Ce}$, hal serupa juga terjadi pada unsur-unsur LTJ lainnya.

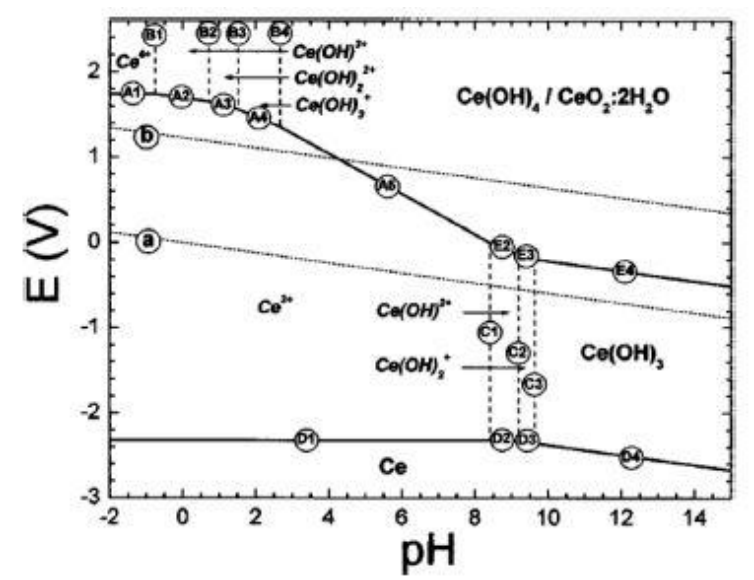

Gambar 10. Diagram Pourbaix sistem $\mathrm{Ce}-\mathrm{H}_{2} \mathrm{O}$ pada $25^{\circ} \mathrm{C}$ [18]. 


\section{KESIMPULAN}

Semakin lama waktu proses digesti asam, persentase ekstraksi Th cenderung meningkat dan mencapai harga maksimum pada $82,5 \%$. Digesti asam selama 60 menit pada berbandingan padat/cair 1:2 $(\mathrm{g} / \mathrm{mL})$ dianggap sebagai waktu proses terbaik karena menghasilkan perolehan Th sebesar 82,5\%, dengan $\mathrm{Fe}$ dan LTJ terlarut masing-masing sebesar $80,1 \%$ dan $83,3 \%$. Peningkatan waktu pengadukan lebih dari 60 menit menyebabkan peningkatan besi yang ikut terlarut sekitar $18 \%$ menjadi $98 \%$ (pada waktu pelindian selama 120 menit atau lebih).

Persentase ekstraksi besi semakin meningkat dengan meningkatnya rasio padat/cair tetapi persentase ekstraksi LTJ cenderung menurun. Rasio padat/cair yang paling baik diperoleh pada 1:2 $(\mathrm{g} / \mathrm{mL})$ dengan persentase ekstraksi thorium dan LTJ tertinggi, yaitu masing-masing sebesar $82,47 \%$ dan $83,31 \%$, sementara persentase ekstraksi Fe sebesar 80,08\%.

Semakin tinggi $\mathrm{pH}$ larutan pada proses presipitasi baik dengan pre-oksidasi atau tanpa pre-oksidasi, semakin banyak Th, Fe, dan LTJ yang terpresipitasi. Presipitasi Th, $\mathrm{Fe}$, dan LTJ paling tinggi dicapai pada $\mathrm{pH}$ larutan 4,5. Semakin tinggi temperatur pada proses presipitasi di $\mathrm{pH}$ 3,5 baik dengan preoksidasi atau tanpa pre-oksidasi, persentase presipitasi $\mathrm{Fe}$ cenderung stabil tetapi Th dan LTJ cenderung menurun. Pada suhu $70^{\circ} \mathrm{C}$ dan tanpa pre-oksidasi diperoleh persentase presipitasi Th tertinggi, yaitu sebesar $83,69 \%$. Sementara untuk presipitasi dengan preoksidasi, persentase presipitasi Th tertinggi sebesar $58,50 \%$ diperoleh pada suhu $80^{\circ} \mathrm{C}$ dan persentase presipitasi LTJ yang sangat rendah, yaitu 1,25\%.Penambahan $\mathrm{H}_{2} \mathrm{O}_{2} 25 \%$ sebanyak dua kali stoikiometri terhadap $\mathrm{Fe}$ terlarut dapat mengendapkan besi terlarut lebih banyak pada $\mathrm{pH}$ yang lebih rendah (29\% lebih banyak daripada presipitasi tanpa pre-oksidasi pada $\mathrm{pH} 3$ ).

\section{UCAPAN TERIMA KASIH}

Penulis mengucapkan terimakasih kepada Pusat Teknologi Bahan Galian Nuklir (PTBGN)-BATAN, Jakarta yang telah menyediakan bahan penelitian serta fasilitas laboratorium proses dan analisis.

\section{DAFTAR PUSTAKA}

[1] BP, "BP Energy Outlook Energy 2017," BP Stat. Rev. World Energy, p. 52, 2017.

[2] Secretary General of National Energy Council, "Indonesia Energy Outlook 2016," pp. 1-129, 2016.

[3] R. Indonesia, "Perpres 22 Tahun 2017.pdf." 2017.

[4] E. Dewita, "Analisis Potensi Thorium Sebagai Bahan Bakar Nuklir Alternatif PLTN," $J$. Pengemb. Energi Nukl., vol. 14, no. Juni 2012, pp. 45-56, 2012.

[5] T. Burke, "The Characterization of Commercial Thorium Oxide Powders," in Bettis Atomic Power Laboratory Report WAPD-TM-1508, 1982.

[6] K. Trinopiawan, M. Z. Mubarok, J. Mellawati, and B. Y. Ani, "Rare Earth Elements Leaching From Tin Slag Using Acid Chloride After Alkaline Fusion Process," Eksplorium, vol. 37, no. 1 , pp. 41-50, 2016

[7] N. Krishnamurthy and C. K. Gupta, Extractive Metallurgy of Rare Earths, Second Edi. 2016.

[8] Suyanti and Suprihati, "Pemurnian torium dengan memakai tributil fosfat," 2010.

[9] K. G. Shaw, "A process for separating thorium compounds from monazite sands," Chem. Eng., 1953.

[10] M. Benedict, Nuclear Chemichal Engineering, 2nd Editio. McGraw-Hill Book Company, 1981.

[11] Z. Talip, M. Eral, and U. Hiçsonmez, "Adsorption of thorium from aqueous solutions by perlite," J. Environ. Radioact., vol. 100, pp. 139-143, 2009.

[12] R. Prasad and A. K. Dey, Studies of Precipitation of Thorium Hydroxide. Springer-Verlag, 1961.

[13] M. Z. Mubarok and A. Dilova, "Atmospheric Leaching Behaviorof East Java Chalcopyrite Ore in Sulfuric Acid Solution and Hydrogen Peroxide as Oxidizing Agent," in Proceedings of International Symposium on Earth Science and Technology, 2013.

[14] H. Li, The Solubilities of Oxygen in Sulphuric Acid Solutions Containing and/or Nickel Sulphate at Atmospheric and High Pressures. Canada: 
University of Ottawa, 1994.

[15] R. A. Hasty and J. E. Boggs, "Formation and Properties," J. Less Common Met., vol. 13, no. 16, pp. 218-222, 1974.

[16] L. Pissarjewski, "Die Superoxyde des Zirkoniums, Ceriums und Thoriums," J. Inorg. Gen. Chem., vol. Vol. 25, no. No 2, pp. 378-398, 1900.

[17] R. D. Abreu and C. A. Morais, "Purification of rare earth elements from monazite sulphuric acid leach liquor and the production of high-purity ceric oxide," Miner. Eng., vol. 23, no. 6, pp. 536540, 2010.

[18] P. Yu, S. A. Hayes, T. J. O’Keefe, M. J. O’Keefe, and J. O. Stoffer, "The Phase Stability of Cerium Species in Aqueous Systems: II. The Ce (III/IV)$\mathrm{H} 2 \mathrm{O}-\mathrm{H} 2 \mathrm{O} 2 \mathrm{O} 2 \quad$ Systems. Equilibrium Considerations and Pourbaix Diagram Calculations," J. Electrochem. Soc., vol. 153, no. 1, pp. C74-C79, 2006. 